\title{
EDITORIAL
}

\section{Cambios en las infecciones entéricas}

\author{
CHANGES IN ENTERIC INFECTIONS
}

Quienes escriben la historia de los pueblos ponen el mayor énfasis en los cambios políticos que van moldeando las naciones, a través de invasiones, conquistas, revoluciones, migraciones y otros hechos similares, en general plenos de violencia y de dolor. Mucho hay que escarbar, para encontrar, en páginas secundarias, algunas escuetas notas sobre los cambios verdaderamente trascendentes que el hombre va logrando, esto es, las mutaciones en las costumbres y formas de vida cotidiana, que siempre se han logrado como fruto de la globalización, término hoy tan en boga, y que no es sino la influencia irresistible de lo mejor. Una constante tendencia hacia la globalización ha existido siempre, en el sentido de ir incorporando adelantos a partir de las naciones más avanzadas: la diferencia es que hoy es la tendencia se convierte en realidad mucho más rápido, gracias al vertiginoso avance de las comunicaciones.

La higiene, entendida en su concepto original, es un buen ejemplo en este sentido. Relegada a párrafos secundarios en los textos de historia, podemos seguir su desarrollo a través de los tiempos. Aunque agitada por guerras permanentes, Europa fue capaz de ir integrando en los siglos XIX y XX conceptos sobre conservación de alimentos, disposición de excretas, necesidad de agua potable y muchos otros, que atravesaron el océano hacia América junto con la moda, el arte y las costumbres sociales.

Chile no podía quedarse atrás. Quienes vivimos, con cierto fatalismo médico, la era de las infecciones entéricas, no podíamos explicarnos su preponderancia, en abierto contraste con un sistema de salud modelo, inserto en una medicina bastante avanzada para el nivel latinoamericano, y confiábamos en dominar estas enfermedades vergonzosas mediante dramáticas medidas, incluyendo vacunaciones masivas, filtración de aguas servidas o drásticas prohibiciones de siembras en determinados terrenos. El cambio favorable llegaría con el convencimiento de la población sobre la utilidad de algunas buenas prácticas, incentivado por el temor que desencadenara el arribo a las costas de Perú de una enfermedad cuyo nombre evocaba devastación.

Una sostendida campaña de información por parte del MINSAL, en que prensa y televisión jugaron un papel relevante, logró cambiar hábitos en la sociedad chilena: en El Mercurio del 14 de septiembre de 1984 aparecía una caricatura mostrando una criatura espantable, denominada FT (en abierta alusión al alienígena ET de un film exitoso de esa época), con la leyenda "Una película no recomendable, combátala previniéndose" y bajo el título global de "Descenso en $40 \%$ de la fiebre tifoidea en relación a 1983 informó MINSAL".

Es indiscutible que las medidas sanitarias implantadas por las autoridades de salud para 
el control de la siembra y comercialización de hortalizas, entre otras, fueron el factor decisivo, y no una vacunación irregular y no evaluable, como parecía insinuar la nota de prensa, pero nada se habría logrado sin la aceptación, nacida de un convencimiento íntimo, por parte de la población chilena, tremendamente disciplinada en materias de salud. Esta aceptación venía gestándose en los niveles más ilustrados de la nación, que veían cuan distintas eran las prácticas en los países desarrollados. Así como íbamos tomando de éstos hábitos y costumbres sociales, vestimentas y alimentos, fuimos copiando también prácticas higiénicas... y esto es globalización.

Pero las bacterias no dan tregua. El desarrollo, que se llevó a la tifoidea y a buena parte de las diarreas del lactante, nos trajo el relevo por parte de otra Salmonella, a consecuencias de la industrialización y masificación de un proceso que antes tenía sólo una magnitud más bien artesanal. Nuevamente tenemos que mirar hacia las naciones más avanzadas, globalizarnos y adoptar las buenas normas de quienes en un momento pasaron por la misma etapa que ahora nos aflige. Sin duda lograremos otra vez mejorar las prácticas y controlar esta amenaza hasta niveles aceptables, pero es indiscutible que éste es un ejemplo notable de los desafios que de continuo nos esperan a los infectólogos. Los nichos ecológicos no son una ficción y el progreso puede producir dramáticas distorsiones de ellos.

Walter Ledermann D.

Unidad de Infectología

Servicio de Pediatría

Hospital Luis Calvo Mackenna 